Supplement of SOIL, 7, 107-123, 2021

https://doi.org/10.5194/soil-7-107-2021-supplement

(c) Author(s) 2021. CC BY 4.0 License.

(c) (i)

Supplement of

\title{
Modelling of long-term $\mathrm{Zn}, \mathrm{Cu}, \mathrm{Cd}$ and $\mathrm{Pb}$ dynamics from soils fertilised with organic amendments
}

Claudia Cagnarini et al.

Correspondence to: Claudia Cagnarini (ccagnar@ceh.ac.uk)

The copyright of individual parts of the supplement might differ from the article licence. 


\section{Supporting Information}

\section{Description of the IDMM}

The IDMM simulates a topsoil as a single, fully-mixed soil layer and computes concentrations of metals associated with the soil and in the soil porewater on an annual basis. The soil layer has a defined depth and comprises fine earth material (the soil material itself), coarse matter (stones) and porespace, which is partly filled by water. Annual gains and losses of metal $\left(\mathrm{mol} \mathrm{m}^{-2} \mathrm{r}^{-1}\right)$ are computed by a flux balance:

$$
\Delta \mathrm{M}=\mathrm{M}_{\mathrm{t}}+F_{\text {input }}+F_{\text {weath }}-F_{\text {drain }}-F_{\text {crop }}
$$

where $\Delta \mathrm{M}$ is the change in metal pool $\left(\mathrm{mol} \mathrm{m}^{-2}\right), \mathrm{M}_{\mathrm{t}}$ is the metal pool in the soil before

calculation $\left(\mathrm{mol} \mathrm{m}{ }^{-2}\right)$ and $F_{\text {input }}, F_{\text {weath }}, F_{\text {drain }}, F_{\text {crop }}$ are respectively the fluxes of metal into the soil in external input and weathering of metal the coarse fraction, and losses in porewater drainage and due to cropping.

Within the soil, metal is subdivided into a number of forms according to Figure 2A. These are:

1. Metal in porewater, comprising the free metal ion and metal complexed to solution ligands, including dissolved organic matter (DOM);

2. Adsorbed metal, comprising metal reversibly adsorbed to binding sites on the surface of the fine earth material. The sum of the adsorbed metal and the metal in porewater is the 'labile' or 'geochemically active' metal, considered measurable by extraction using a strong ligand or dilute acid (e.g. 0.1M EDTA, 0.43M $\mathrm{HNO}_{3}$ ).

3. Two pools of 'aged' metal. This is metal in the fine earth that is considered 'fixed' within the solid phase and only slowly exchangeable with the labile pool. The two pools are characterised by relatively fast and slow exchange kinetics and are termed the 'aged' and 'mineral' pools. 
Chemical speciation of the labile metal, including its distribution between the solid phase and porewater, is handled by equilibrium, while exchanges of metal among the labile, weakly aged

\begin{tabular}{|c|c|c|c|c|c|c|}
\hline \multirow{3}{*}{ e handled by } & \multicolumn{5}{|c|}{ Limits of quantification } & aged pools \\
\hline & & $\mathrm{Zn}$ & $\mathrm{Cu}$ & $\mathrm{Pb}$ & $\mathrm{Cd}$ & \multirow{3}{*}{ kinetics. } \\
\hline & EDTA [mg kg-1] & 0.4 & 0.1 & 0.06 & 0.02 & \\
\hline ation $a$ & TOT [mg kg-1] & 0.2 & 0.3 & ב0 0 & 001 & \\
\hline
\end{tabular}

of the labile metal pool

The equilibrium speciation and solid-porewater distribution of the labile metal pool is computed annually by a combination of empirical modelling and application of the WHAM/Model VI speciation code (Tipping, 1998). Empirical modelling, following the approach of Groenenberg et al. (2010), is used to derive the relationship between the free metal ion concentration in the porewater and the adsorbed metal concentration, as a function of key soil properties:

$$
\log K_{f . m}=\log \left\{\mathrm{M}_{\mathrm{ads}}\right\}-n \cdot \log \left[\mathrm{M}^{2+}\right]=\gamma_{1}+\gamma_{2} \cdot \mathrm{pH}_{\mathrm{pw}}+\gamma_{3} \cdot \log \{\mathrm{SOM}\}
$$

Here $\log K_{f . m}$ is a Freundlich-type partition coefficient, defined as $\log \left\{\mathrm{M}_{\mathrm{ads}}\right\}-n \cdot \log \left[\mathrm{M}^{2+}\right]$ where $\left\{M_{a d s}\right\}$ is the adsorbed metal concentration $\left(m o l g^{-1}\right),\left[\mathrm{M}^{2+}\right]$ is the free metal ion concentration in porewater $\left(\mathrm{mol} \mathrm{dm}{ }^{-3}\right)$ and $n$ is a fitted constant in the range zero to unity. The terms $\mathrm{pH}_{p w}$ and $\{\mathrm{SOM}\}$ are the porewater $\mathrm{pH}$ and the soil organic matter content $(\% \mathrm{w} / \mathrm{w})$ respectively, and the $\gamma$ terms are fitted constants. The model is optimised by fitting to the error in $\log K_{f . m}$; this drives a set of constants that provide consistent computation of $\left\{\mathrm{M}_{\mathrm{ads}}\right\}$ from $\left[\mathrm{M}^{2+}\right]$ and vice versa. The constants used are taken from Groenenberg et al. (2010) and are shown in

Table S1: Limits of quantification of total and EDTA-extractable concentrations for $\mathrm{Zn}, \mathrm{Cu}$, $\mathrm{Pb}$ and $\mathrm{Cd}$. 



\section{Table S2.}

The relationship between the free metal ion and dissolved metal in the porewater is handled by WHAM/Model VI. Inputs to the model comprise the porewater $\mathrm{pH}$ and dissolved concentrations of $\mathrm{Na}, \mathrm{Mg}, \mathrm{Ca}, \mathrm{Cl}$ and $\mathrm{SO}_{4}$, and the DOM concentration. These variables are all specified. An initial adjustment is made, whereby either the concentration of $\mathrm{Ca}$, or those of $\mathrm{Cl}$ and $\mathrm{SO}_{4}$, are adjusted to achieve charge balance at the specified $\mathrm{pH}$. The speciation of $\mathrm{Al}$ is handled using the approach of Tipping (2005) to estimate the activity of $\mathrm{Al}^{3+}$ in the porewater on the basis of the $\mathrm{pH}$ and DOM concentration. The speciation of FeIII is handled by assuming the porewater $\mathrm{Fe}^{3+}$ to be in equilibrium with $\mathrm{Fe}(\mathrm{OH})_{3}$, having a standard solubility constant of 2.5 and a standard enthalpy of $-102 \mathrm{~kJ} \mathrm{~mol}^{-1}$.

The equilibrium constants used are shown in Table S3 and 


\section{Table S4.}

Metal binding to DOM is simulated by assuming it to comprise $65 \%$ fulvic acid. Each metal has two binding constants, (i) $\log K_{\mathrm{MA}}$ which is used to derive binding constants for carboxylic and phenolic binding sites, and (ii) $\Delta L K_{2}$, which is used to generate constants for high affinity binding sites. Parameters are shown in Table S5.

\section{Exchange among labile, and aged pools}

Metal exchanges between the labile, weakly aged and strongly aged pools are handled by a first order kinetic schema as introduced by $\mathrm{Xu}$, Lofts and $\mathrm{Lu}$ (2016). The schema allows the following transfers of metal among the pools: (i) labile to weakly aged, (ii) weakly aged to labile, (iii) weakly aged to strongly aged, and (iv) strongly aged to labile. These transfers are described by the kinetic constants $k_{\mathrm{f}, \mathrm{a}}, k_{\mathrm{b}, \mathrm{a}}, k_{\mathrm{f}, \mathrm{m}}$ and $k_{\mathrm{b}, \mathrm{m}}$ respectively. These are summarised in Table S6.

Aging constants for $\mathrm{Pb}$ were derived by analysis of an ongoing long term experiment, comprising four UK soils. Soils were spiked with lead and incubated with maintenance of temperature and moisture content (55\% of water holding capacity). Samples were periodically taken for quantification of lead spike lability using isotopic dilution. Fitting results are shown in Figure S2.

\section{IDMM initialisation}

The IDMM is initialised for a starting simulation year where inputs are assumed to derive from only natural sources, i.e. atmospheric deposition of geogenic metal, and mineral weathering.

Metal fluxes within the soil layer are assumed to be in steady state, such that the output flux in drainage is equal to the natural input fluxes (the crop offtake flux is assumed to be zero). Based on this assumption, the porewater metal concentrations are computed and then the adsorbed 
and aged concentrations by backcalculation. The aged concentrations are assumed to be in equilibrium with the adsorbed concentrations. The kinetic constant $k_{\mathrm{b}, \mathrm{m}}$ (Table S6), describing the rate of transformation of strongly aged metal to labile metal, is varied by adjusting it to force the total concentration to match a define value. For this work, we optimised $k_{\mathrm{b}, \mathrm{m}}$ by adjusting it to optimise the modelled total metal concentration trend to optimally match the first three measurements of the total concentration of each metal in the NIL plot. Optimised values are shown in Table S6. The IDMM thus makes absolute predictions of the labile metal concentration, for a given set of the supplied metal input time series and the initial assumption of steady state, but must be optimised to match observed total metal concentrations and is thus best described as making predictions of the trend in total metal concentration.

\section{Critical limit concentrations for metals}

Critical limits are after Lofts et al. (2004). The limits are functions of the porewater $\mathrm{pH}$ and soil organic matter concentration and take the form

$$
\{\mathrm{M}\}_{\mathrm{lab}, \mathrm{crit}}=f \cdot \mathrm{pH}_{\mathrm{pw}}+g \cdot \log \mathrm{OM}+y
$$

where $\{\mathrm{M}\}_{\text {lab,crit }}$ is the critical labile concentration $\left(\mathrm{mg} \mathrm{kg}^{-1}\right), \mathrm{pH}_{\mathrm{pw}}$ is the porewater $\mathrm{pH}, \mathrm{OM}$ is the soil organic matter content and $f, g, y$ are fitted parameters.

Parameter values for critical limits protective of $95 \%$ of species are shown in Table S7, and Figure S3 shows example time trends in critical limit concentrations for the SS plot. The decreases in the limit concentrations are driven by declines in the SOM content and porewater $\mathrm{pH}$ of the soil.

\section{Metal input flux estimation}


Besides TE inputs from the organic amendments, TE inputs to the plots were assumed to comprise geogenic and anthropogenic deposition from the atmosphere, and mineral weathering from the coarse $(>2 \mathrm{~mm})$ fraction of soil.

In analogy to the work of Rieder et al. (2014) for a Swiss forest, geogenic deposition (mainly by volcanic eruptions) was estimated by averaging the metal enrichment factors (EFs) reported for $\mathrm{Zn}, \mathrm{Cu}, \mathrm{Pb}, \mathrm{Cd}$ by Shotyk et al. (2002) in the deep layers (deposited before 1905) of a peat bog in the Jura Mountains, Switzerland. The mean EFs were converted into actual atmospheric depositions by using the transfer functions reported by Thoni et al. (1996), which relate metal concentrations in moss and atmospheric deposition in Switzerland. The estimated geogenic deposition rates were: $7.5 .10^{-2} \mathrm{mg} \mathrm{m}^{-2} \mathrm{a}^{-1}$ for $\mathrm{Zn}, 7.10^{-2} \mathrm{mg} \mathrm{m}^{-2} \mathrm{a}^{-1}$ for $\mathrm{Cu}, 0.52 \mathrm{mg} \mathrm{m}^{-2} \mathrm{a}^{-1}$ for $\mathrm{Pb}$ and $1.1 .10^{-2} \mathrm{mg} \mathrm{m}^{-2} \mathrm{a}^{-1}$ for $\mathrm{Cd}$.

Rates of anthropogenic atmospheric deposition of $\mathrm{Zn}, \mathrm{Cu}$, and $\mathrm{Cd}$ before 1990 were estimated using EFs reported by Shotyk et al. (2002). For Pb, EFs before 1990 were taken from Weiss et al. (1999), by averaging of results from peat bog sites with annual precipitation rates similar to those at ZOFE. From 1990 to 2014 atmospheric deposition data were estimated from metal concentrations in mosses sampled from site in Northern Switzerland (BAFU, 2018). These concentrations were converted into atmospheric deposition rates using the transfer functions of Thoni et al (1996) (Figure S4).

Data on TE weathering rates in topsoils are generally very limited. So, instead of making estimates of weathering rates from independent data, we fitted apparent weathering rates by applying the model to the NIL plot (where no metal inputs due to organic amendment occur) and adjusting the apparent weathering rate to force the modelled labile concentration to match the first three time series measurements of the EDTA-extractable TE concentration. Model predictions of the labile TE concentration in the absence of an apparent weathering rate were 
consistently biased to low values, suggesting the presence of an additional labile TE input. We tentatively ascribe this term to mineral weathering, however in practice it simply accounts for the discrepancy observed and labile TE based

\begin{tabular}{|l|r|}
\hline \multicolumn{2}{|c}{ Limits of } \\
\hline & Z \\
\hline EDTA [mg kg-1] & 0.4 \\
\hline TOT [mg kg-1] & 0. \\
\hline
\end{tabular}

\begin{tabular}{|c|c|c|c|}
\hline \multicolumn{5}{|c|}{ quantification } \\
\hline Zn & $\mathrm{Cu}$ & $\mathrm{Pb}$ & $\mathrm{Cd}$ \\
\hline .4 & 0.1 & 0.06 & 0.02 \\
\hline .2 & 0.3 & 0.02 & 0.01 \\
\hline
\end{tabular}
between computed on our estimates of atmospheric deposition, and so compensates for any bias present in deposition estimates. It may also account for any unknown historic inputs of TE prior to the establishment of the experiment. The site history does suggest that there is likely to be a contribution from past input of fungicides to the labile $\mathrm{Cu}$ concentrations at the beginning of the measurement period. Following optimisation the effective weathering rates were used for all simulations in all the plots.

The $\mathrm{Zn}$ and $\mathrm{Cu}$ inputs in manure were calculated by multiplying manure $\mathrm{Zn}: \mathrm{P}$ and $\mathrm{Cu}: \mathrm{P}$ ratios with the known input rates of $\mathrm{P}$ in manure. Menzi and Kessler (1998) analysed a wide database of FYM samples and reported stable average concentrations of $\mathrm{Zn}$ and $\mathrm{Cu}$ per unit of $\mathrm{P}$. In this case, the $\mathrm{Zn}: \mathrm{P}$ and $\mathrm{Cu}: \mathrm{P}$ ratios were averaged from the values measured in the farmyard manure samples applied to ZOFE in 2011 and 2014 (

Table S1: Limits of quantification of total and EDTA-extractable concentrations for $\mathrm{Zn}, \mathrm{Cu}$, $\mathrm{Pb}$ and $\mathrm{Cd}$.

). To take into account the strong reduction of $\mathrm{Zn}$ and $\mathrm{Cu}$ contents in FYM observed starting from the 1990s, as a consequence of the decreased supply of TEs in animal forage (de Vries et al., 2004; Groenenberg et al., 2006; Menzi and Kessler, 1998), stepwise reductions of 0.7 and 0.52 were imposed on these ratios for $\mathrm{Zn}$ and $\mathrm{Cu}$, respectively, from 1999 onwards. The $\mathrm{Pb}$ 
and $\mathrm{Cd}$ inputs in manure were also calculated from the $\mathrm{P}$ content, using $\mathrm{Pb}: \mathrm{P}$ and $\mathrm{Cd}: \mathrm{P}$ ratios of 0.495 and 0.027 , respectively, taken from the work of Menzi and Kessler (1998) (total

\begin{tabular}{|c|c|c|c|c|c|}
\hline $\begin{array}{l}\text { concentrations of } \\
\text { FYM samples }\end{array}$ & \multicolumn{5}{|c|}{ Limits of quantification } \\
\hline \multirow{2}{*}{ FYM samples } & & $\mathrm{Zn}$ & $\mathrm{Cu}$ & $\mathrm{Pb}$ & $\mathrm{Cd}$ \\
\hline & EDTA [mg kg-1] & 0.4 & 0.1 & 0.06 & 0.02 \\
\hline id 2014 & TOT [mg kg-1] & 0.2 & 0.3 & 0.02 & 0.01 \\
\hline
\end{tabular}

$\mathrm{Pb}$ and $\mathrm{Cd}$ in from 2011 analytically quantified). The P content in the FYM applied to ZOFE has been measured throughout the experiment and ranged from $0.018 \%$ to $0.098 \% \mathrm{w} / \mathrm{w}$. The estimated metal inputs in manure are shown in Figure S5. Smoothed input trends were used in the model to reduce the effect of noise on the simulations. A five-year period, four pass averaging approach was used for smoothing.

The TE concentrations measured in the green waste compost samples applied in 2011, 2013 and 2014(

Table S1: Limits of quantification of total and EDTA-extractable concentrations for $\mathrm{Zn}, \mathrm{Cu}$, $\mathrm{Pb}$ and $\mathrm{Cd}$.

) were averaged and assumed to be constant throughout the experiment. For $\mathrm{Cd}$, which was below the instrument limit of quantification, a value of $0.13 \mathrm{mg} \mathrm{kg}^{-1}$ was used, based on a nationwide investigation of compost quality in Switzerland. Estimated and smoothed metal inputs in compost are shown in Figure S5, with the smoothed trends used in the simulations.

Two approaches were used to estimate TE inputs due to sewage sludge addition. In the first approach, which we term 'Swiss Trend', TE concentrations measured in sludge samples from 2008 and 2012( 
Table S1: Limits of quantification of total and EDTA-extractable concentrations for $\mathrm{Zn}, \mathrm{Cu}$, $\mathrm{Pb}$ and $\mathrm{Cd}$.

\begin{tabular}{|l|c|c|c|c|}
\hline \multicolumn{5}{|c|}{ Limits of quantification } \\
\hline & $\mathrm{Zn}$ & $\mathrm{Cu}$ & $\mathrm{Pb}$ & $\mathrm{Cd}$ \\
\hline EDTA [mg kg-1] & 0.4 & 0.1 & 0.06 & 0.02 \\
\hline TOT [mg kg-1] & 0.2 & 0.3 & 0.02 & 0.01 \\
\hline
\end{tabular}

) were averaged and assumed to be representative for 2000-2014. For 1975-2000, the exponential decrease in sludge TE contents reported by Kulling et al. (2001) for sewage sludge in Switzerland was applied to the measured values; before 1975 the TE concentrations were kept constant and equal to the values calculated in 1975. In the second approach, termed 'Idealised Trend', the constant TE concentrations prior to 1975 were adjusted to fit the first three observed EDTA-extractable TE concentrations. The metal inputs were determined by multiplying the metal concentrations, as estimated according to the two approaches described above, by the amount of sewage sludge applied (Figure S6).

\section{References}

Baes C.F., Mesmer A.E. (1976). The Hydrolysis of Cations. John Wiley \& Sons, New York.

BAFU (Hrsg.) 2018: Deposition von Luftschadstoffen in der Schweiz. Moosanalysen 1990 2015. Bundesamt für Umwelt, Bern. Umwelt-Zustand Nr. 1818: 134 S.

Buffle J., Chalmers R.A., Masson M.R., Midgley D. (1988). Complexation reactions in aquatic systems : an analytical approach. Ellis Horwood, Chichester.

De Vries W., Römkens P.F.A.M., Voogd J.C.H. (2004). Prediction of the long term accumulation and leaching of copper in Dutch agricultural soils: A risk assessment study (Rapport 1030), Alterra Green World Research, Wageningen, The Netherlands 
Groenenberg, J.E., Römkens, P.F.A.M. \& De Vries, W. (2006). Prediction of the long term accumulation and leaching of copper in Dutch agricultural soils: A risk assessment study (Rapport 1278), Alterra Green World Research, Wageningen, The Netherlands.

Groenenberg J.E., Romkens P.F.A.M., Comans R.N.J., Luster J., Pampura T., Shotbolt L., de Vries W. (2010). Transfer functions for solid-solution partitioning of cadmium, copper, nickel, lead and zinc in soils: derivation of relationships for free metal ion activities and validation with independent data. European Journal of Soil Science, 61(1), 58-73. doi:10.1111/j.13652389.2009.01201.x

Izatt R.M., Eatough J.J., Christensen J.J. and Bartholomew C.H. (1969) Calorimetrically determined $\log \mathrm{K}$, deltaH_0 and deltaS_0 values for the interaction of sulphate ion with several bi- and ter-valent metal ions. J. Chem. Soc. (A) 47-53.

Kulling D., Stadelmann F., Herter U. (2001) Sewage Sludge-Fertilizer or Waste? UKWIR Conference, Brussels.

Kupper, T., Burge, D., Bachmann, H. J., Gusewell, S., \& Mayer, J. (2014). Heavy metals in source-separated compost and digestates. Waste Management, 34(5), 867-874. doi:10.1016/j.wasman.2014.02.007

Mattigod S.V., Sposito G. (1979). Chemical Modeling of Trace Metal Equilibria in contaminated soil solutions using the computer program, GEOCHEM. In: Chemical Modeling in Aqueous Systems: Speciation, Sorption, Solubility. Ed. E. Jenne. ACS Symposium Series 93, American Chemical Society, Washington DC.

May H.M., Helmke P.A., Jackson M.L. (1979) Gibbsite solubility and thermodynamic properties of hydroxy-aluminium ions in aqueous solution at $25^{\circ} \mathrm{C}$. Geochimica et Cosmochimica Acta, 43, 861-868. 
Menzi H., Kessler J., 1998. Heavy metal content of manures in Switzerland. In: Martinez,J., Maudet,M. (Eds.),RAMIRAN 98.Proc. 8th Int. Conference of the FAO ESCORENA Network on Recycling of Agricultural, Municipal, and Industrial Residues in Agriculture. Rennes, France, 26-29 May 1998, FAO and Cemagref, France, pp. 495-506

NIST (2003). NIST Standard Reference Database 46 - NIST critically selected stability constants of metal complexes: version 7.0. National Institute of Standards and Technology, US Department of Commerce.

Nordstrom D.K., Plummer L.N., Langmuir D., Busenberg E., May H.M., Jones B.F., Parkhurst D.L. (1990) Revised chemical equilibrium data for major water-mineral reactions and their limitations In: Chemical modeling of aqueous systems II. Eds. D. C. Melchior, R. L.Bassett. ACS Symposium Series 416, p. 398-413, American Chemical Society, Washington DC.

Parkhurst D.L., Appelo C.A.J. (1999). User's guide to PHREEQC (version 2) - a computer program for speciation, batch-reaction, one-dimensional transport, and inverse geochemical calculations. US Geological Survey, Denver, Colorado.

Rieder S.R., Tipping E., Zimmermann S., Graf-Pannatier E., Waldner P., Meili M., \& Frey B. (2014). Dynamic modelling of the long term behaviour of cadmium, lead and mercury in Swiss forest soils using CHUM-AM. Science of the Total Environment, 468, 864-876. doi:10.1016/j.scitotenv.2013.09.005

Sillen L.G. and Martell A.E. (1971) Stability Constants of Metal-Ion Complexes, Suppl. No. 1. Chemical Society, London.

Shotyk W., Krachler M., Martinez-Cortizas A., Cheburkin A. K., \& Emons H. (2002). A peat bog record of natural, pre-anthropogenic enrichments of trace elements in atmospheric aerosols since 12370 C-14 yr BP, and their variation with Holocene climate change. Earth and Planetary Science Letters, 199(1-2), 21-37. doi:Pii S0012-821x(02)00553-8 
Smith R.M. and Martell A.E. (1976). Critical Stability Constants, Vol. 4: Inorganic Complexes. Plenum Press, New York.

Sunda W.G., Hanson P.J. (1979). Chemical Speciation of Copper in River Water: Effect of Total Copper, pH, Carbonate, and Dissolved Organic Matter. In: Chemical Modeling in Aqueous Systems: Speciation, Sorption, Solubility. Ed. E. Jenne. ACS Symposium Series 93, American Chemical Society, Washington DC.

Thoni L., Schnyder N., \& Krieg F. (1996). Comparison of metal concentrations in three species of mosses and metal freights in bulk precipitations. Fresenius Journal of Analytical Chemistry, 354(5-6), 703-708.

Tipping E. (1998). Humic Ion-Binding Model VI: An improved description of the interactions of protons and metal ions with humic substances. Aquatic Geochemistry, 4(1), 3-48. doi: 10.1023/A:1009627214459

Tipping E. (2005). Modelling Al competition for heavy metal binding by dissolved organic matter in soil and surface waters of acid and neutral pH. Geoderma, 127, 293-304. doi:10.1016/j.geoderma.2004.12.003

Tipping E., Rey-Castro,C., Bryan S.E., Hamilton-Taylor J. (2002). Al(III) and Fe(III) binding by humic substances in freshwaters, and implications for trace metal speciation. Geochimica et Cosmochimica Acta, 66(18), 3211-3224. doi: 10.1016/S0016-7037(02)00930-4

Weiss D., Shotyk W., Appleby P.G., Kramers I.D., \& Cheburkin A.K. (1999). Atmospheric Ph deposition since the industrial revolution recorded by five Swiss peat profiles: Enrichment factors, fluxes, isotopic composition, and sources. Environmental Science \& Technology, 33(9), 1340-1352. doi:DOI 10.1021/es980882q 
Xu L., Lofts S., \& Lu Y. (2016). Terrestrial ecosystem health under long-term metal inputs: modeling and risk assessment. Ecosystem Health and Sustainability, 2(5), e01214. doi:10.1002/ehs2.1214 
Table S1: Limits of quantification of total and EDTA-extractable concentrations for $\mathrm{Zn}, \mathrm{Cu}$, $\mathrm{Pb}$ and $\mathrm{Cd}$.

\begin{tabular}{|l|c|c|c|c|}
\hline \multicolumn{5}{|c|}{ Limits of quantification } \\
\hline & $\mathrm{Zn}$ & $\mathrm{Cu}$ & $\mathrm{Pb}$ & $\mathrm{Cd}$ \\
\hline EDTA $\left[\mathrm{mg} \mathrm{kg}^{-1}\right]$ & 0.4 & 0.1 & 0.06 & 0.02 \\
\hline TOT $\left[\mathrm{mg} \mathrm{kg}^{-1}\right]$ & 0.2 & 0.3 & 0.02 & 0.01 \\
\hline
\end{tabular}


Table S2. Parameters for adsorbed metal-free ion relationships, adapted from Groenenberg et al., 2010

\begin{tabular}{|l|c|c|c|c|}
\hline Metal & $\boldsymbol{\gamma}_{\mathbf{1}}$ & $\boldsymbol{\gamma}_{\mathbf{1}}$ & $\boldsymbol{\gamma}_{\mathbf{1}}$ & $\boldsymbol{n}$ \\
\hline $\mathbf{C u}$ & -6.37 & 0.64 & 0.87 & 0.57 \\
\hline $\mathbf{Z n}$ & -4.67 & 0.46 & 0.84 & 0.84 \\
\hline $\mathbf{C d}$ & -5.71 & 0.41 & 0.91 & 0.70 \\
\hline $\mathbf{P b}$ & -6.46 & 0.96 & 1.35 & 0.84 \\
\hline
\end{tabular}


Table S3. Solution equilibrium parameters for $\mathrm{Ca}, \mathrm{Al}, \mathrm{FeIII}$ and carbonate.

\begin{tabular}{|c|c|c|c|}
\hline Equilibrium & $\log K^{\theta}$ & $\Delta \mathbf{H}^{\boldsymbol{\theta}}\left(\mathbf{k J ~ m o l}{ }^{-1}\right)$ & Reference \\
\hline $\mathrm{H}^{+}+\mathrm{CO}_{3}{ }^{2-} \rightleftharpoons \mathrm{HCO}_{3}^{-}$ & 10.329 & -14.899 & Nordstrom et al. (1990) \\
\hline $2 \mathrm{H}^{+}+\mathrm{CO}_{3}^{2-} \rightleftharpoons \mathrm{H}_{2} \mathrm{CO}_{3}$ & 16.681 & -24.008 & Nordstrom et al. (1990) \\
\hline $\mathrm{Mg}^{2+}+\mathrm{H}^{+}+\mathrm{CO}_{3}^{-} \rightleftharpoons \mathrm{MgHCO}_{3}^{+}$ & 11.4 & -11.59 & Nordstrom et al. (1990) \\
\hline $\mathrm{Mg}^{2+}+\mathrm{CO}_{3}^{2-} \rightleftharpoons \mathrm{MgCO}_{3}$ & 2.98 & 11.34 & Nordstrom et al. (1990) \\
\hline $\mathrm{Mg}^{2+}+\mathrm{SO}_{4}^{2-} \rightleftharpoons \mathrm{MgSO}_{4}$ & 2.37 & 19.04 & Nordstrom et al. (1990) \\
\hline $\mathrm{Al}^{3+}+\mathrm{OH}^{-} \rightleftharpoons \mathrm{AlOH}^{2+}$ & 9.01 & -6.44 & $\begin{array}{l}\text { May, Helmke, Jackson } \\
\text { (1979) }\end{array}$ \\
\hline $\mathrm{Al}^{3+}+2 \mathrm{OH}^{-} \rightleftharpoons \mathrm{Al}(\mathrm{OH})_{2}^{+}$ & 17.87 & -15.40 & $\begin{array}{l}\text { May, Helmke, Jackson } \\
\text { (1979) }\end{array}$ \\
\hline $\mathrm{Al}^{3+}+4 \mathrm{OH}^{-} \rightleftharpoons \mathrm{Al}(\mathrm{OH})_{4}^{-}$ & 33.84 & -45.44 & $\begin{array}{l}\text { May, Helmke, Jackson } \\
\text { (1979) }\end{array}$ \\
\hline $\mathrm{Al}^{3+}+\mathrm{SO}_{4}^{2-} \rightleftharpoons \mathrm{AlSO}_{4}^{+}$ & 3.2 & 9.6 & $\begin{array}{l}\text { Izatt, Eatough, Christensen, } \\
\text { Bartholomew (1969) } \\
\text { Sillen and Martell (1971) }\end{array}$ \\
\hline $\mathrm{Al}^{3+}+2 \mathrm{SO}_{4}^{2-} \rightleftharpoons \mathrm{Al}\left(\mathrm{SO}_{4}\right)_{2}^{-}$ & 5.11 & 13.0 & $\begin{array}{l}\text { Izatt, Eatough, Christensen, } \\
\text { Bartholomew (1969) } \\
\text { Sillen and Martell (1971) }\end{array}$ \\
\hline $\mathrm{Ca}^{2+}+\mathrm{H}^{+}+\mathrm{CO}_{3}^{-} \rightleftharpoons \mathrm{CaHCO}_{3}^{+}$ & 11.44 & -3.64 & Nordstrom et al. (1990) \\
\hline $\mathrm{Ca}^{2+}+\mathrm{CO}_{3}{ }^{2-} \rightleftharpoons \mathrm{CaCO}_{3}$ & 3.22 & 14.85 & Nordstrom et al. (1990) \\
\hline $\mathrm{Ca}^{2+}+\mathrm{SO}_{4}^{2-} \rightleftharpoons \mathrm{CaSO}_{4}$ & 2.30 & 6.90 & Nordstrom et al. (1990) \\
\hline $\mathrm{Fe}^{3+}+\mathrm{OH}^{-} \rightleftharpoons \mathrm{FeOH}^{2+}$ & 11.81 & -12.39 & Nordstrom et al. (1990) \\
\hline $\mathrm{Fe}^{3+}+2 \mathrm{OH}^{-} \rightleftharpoons \mathrm{Fe}(\mathrm{OH})_{2}^{+}$ & 22.33 & -40.25 & Nordstrom et al. (1990) \\
\hline $\mathrm{Fe}^{3+}+3 \mathrm{OH}^{-} \rightleftharpoons \mathrm{Fe}(\mathrm{OH})_{3}$ & 29.44 & -63.97 & Nordstrom et al. (1990) \\
\hline $\mathrm{Fe}^{3+}+4 \mathrm{OH}^{-} \rightleftharpoons \mathrm{Fe}(\mathrm{OH})_{4}^{-}$ & 34.4 & -90.17 & Nordstrom et al. (1990) \\
\hline $\mathrm{Fe}^{3+}+\mathrm{SO}_{4}^{2-} \rightleftharpoons \mathrm{FeSO}_{4}^{+}$ & 4.04 & 16.36 & Nordstrom et al. (1990) \\
\hline $\mathrm{Fe}^{3+}+\mathrm{Cl}^{-} \rightleftharpoons \mathrm{FeCl}^{2+}$ & 1.48 & 23.43 & Nordstrom et al. (1990) \\
\hline $\mathrm{Fe}^{3+}+2 \mathrm{Cl}^{-} \rightleftharpoons \mathrm{FeCl}_{2}^{+}$ & 2.13 & - & Nordstrom et al. (1990) \\
\hline
\end{tabular}


Table S4. Solution equilibrium parameters for $\mathrm{Cu}, \mathrm{Zn}, \mathrm{Cd}$ and $\mathrm{Pb}$

\begin{tabular}{|c|c|c|c|}
\hline Equilibrium & $\log K^{\theta}$ & $\Delta \mathbf{H}^{\theta}\left(\mathrm{kJ} \mathrm{mol}^{-1}\right)$ & Reference \\
\hline $\mathrm{Cu}^{2+}+\mathrm{OH}^{-} \rightleftharpoons \mathrm{CuOH}^{+}$ & 6.48 & - & Sunda and Hanson (1979) \\
\hline $\mathrm{Cu}^{2+}+2 \mathrm{OH}^{-} \rightleftharpoons \mathrm{Cu}(\mathrm{OH})_{2}$ & 11.78 & - & Sunda and Hanson (1979) \\
\hline $\mathrm{Cu}^{2+}+\mathrm{H}^{+}+\mathrm{CO}_{3}^{-} \rightleftharpoons \mathrm{CuHCO}_{3}^{+}$ & 14.62 & - & $\begin{array}{l}\text { Mattigod and Sposito } \\
\text { (1979) }\end{array}$ \\
\hline $\mathrm{Cu}^{2+}+\mathrm{CO}_{3}^{2-} \rightleftharpoons \mathrm{CuCO}_{3}$ & 6.75 & - & Smith and Martell (1976) \\
\hline $\mathrm{Cu}^{2+}+2 \mathrm{CO}_{3}^{2-} \rightleftharpoons \mathrm{Cu}\left(\mathrm{CO}_{3}\right)_{2}^{2-}$ & 9.92 & - & Smith and Martell (1976) \\
\hline $\mathrm{Cu}^{2+}+\mathrm{SO}_{4}^{2-} \rightleftharpoons \mathrm{CuSO}_{4}$ & 2.36 & 8.8 & Smith and Martell (1976) \\
\hline $\mathrm{Cu}^{2+}+\mathrm{Cl}^{-} \rightleftharpoons \mathrm{CuCl}^{+}$ & 0.4 & 6.7 & Smith and Martell (1976) \\
\hline $\mathrm{Zn}^{2+}+\mathrm{OH}^{-} \rightleftharpoons \mathrm{ZnOH}^{+}$ & 5.04 & - & Baes and Mesmer (1976) \\
\hline $\mathrm{Zn}^{2+}+2 \mathrm{OH}^{-} \rightleftharpoons \mathrm{Zn}(\mathrm{OH})_{2}$ & 11.1 & - & Baes and Mesmer (1976) \\
\hline $\mathrm{Zn}^{2+}+\mathrm{H}^{+}+\mathrm{CO}_{3}^{-} \rightleftharpoons \mathrm{ZnHCO}_{3}^{+}$ & 13.12 & - & $\begin{array}{l}\text { Mattigod and Sposito } \\
\text { (1979) }\end{array}$ \\
\hline $\mathrm{Zn}^{2+}+\mathrm{CO}_{3}{ }^{2-} \rightleftharpoons \mathrm{ZnCO}_{3}$ & 4.76 & - & $\begin{array}{l}\text { Mattigod and Sposito } \\
\text { (1979) }\end{array}$ \\
\hline $\mathrm{Zn}^{2+}+\mathrm{SO}_{4}^{2-} \rightleftharpoons \mathrm{ZnSO}_{4}$ & 2.38 & 6.3 & Smith and Martell (1976) \\
\hline $\mathrm{Zn}^{2+}+\mathrm{Cl}^{-} \rightleftharpoons \mathrm{ZnCl}^{+}$ & 0.4 & 5.4 & Smith and Martell (1976) \\
\hline $\mathrm{Cd}^{2+}+\mathrm{OH}^{-} \rightleftharpoons \mathrm{CdOH}^{+}$ & 3.92 & - & Baes and Mesmer (1976) \\
\hline $\mathrm{Cd}^{2+}+2 \mathrm{OH}^{-} \rightleftharpoons \mathrm{Cd}(\mathrm{OH})_{2}$ & 7.65 & - & Baes and Mesmer (1976) \\
\hline $\mathrm{Cd}^{2+}+\mathrm{H}^{+}+\mathrm{CO}_{3}^{-} \rightleftharpoons \mathrm{CdHCO}_{3}^{+}$ & 11.83 & - & $\begin{array}{l}\text { Parkhurst and Appelo } \\
\text { (1999) }\end{array}$ \\
\hline $\mathrm{Cd}^{2+}+\mathrm{CO}_{3}{ }^{2-} \rightleftharpoons \mathrm{CdCO}_{3}$ & 4.37 & - & NIST (2003) \\
\hline $\mathrm{Cd}^{2+}+2 \mathrm{CO}_{3}{ }^{2-} \rightleftharpoons \mathrm{Cd}\left(\mathrm{CO}_{3}\right)_{2}{ }^{2-}$ & 7.26 & - & NIST (2003) \\
\hline $\mathrm{Cd}^{2+}+\mathrm{SO}_{4}^{2-} \rightleftharpoons \mathrm{CdSO}_{4}$ & 2.46 & 9.6 & Smith and Martell (1976) \\
\hline $\mathrm{Cd}^{2+}+\mathrm{Cl}^{-} \rightleftharpoons \mathrm{CdCl}^{+}$ & 1.98 & 1.3 & Smith and Martell (1976) \\
\hline $\mathrm{Cd}^{2+}+2 \mathrm{Cl}^{-} \rightleftharpoons \mathrm{CdCl}_{2}$ & 2.6 & 3.8 & Smith and Martell (1976) \\
\hline $\mathrm{Pb}^{2+}+\mathrm{OH}^{-} \rightleftharpoons \mathrm{PbOH}^{+}$ & 6.29 & - & Baes and Mesmer (1976) \\
\hline $\mathrm{Pb}^{2+}+2 \mathrm{OH}^{-} \rightleftharpoons \mathrm{Pb}(\mathrm{OH})_{2}$ & 10.88 & - & Baes and Mesmer (1976) \\
\hline $\mathrm{Pb}^{2+}+3 \mathrm{OH}^{-} \rightleftharpoons \mathrm{Pb}(\mathrm{OH})_{3}^{-}$ & 13.94 & - & Baes and Mesmer (1976) \\
\hline $\mathrm{Pb}^{2+}+\mathrm{CO}_{3}^{2-} \rightleftharpoons \mathrm{PbCO}_{3}$ & 7.2 & - & $\begin{array}{l}\text { Buffle, Chalmers, Masson, } \\
\text { Midgley (1988) }\end{array}$ \\
\hline $\mathrm{Pb}^{2+}+2 \mathrm{CO}_{3}{ }^{2-} \rightleftharpoons \mathrm{Pb}\left(\mathrm{CO}_{3}\right)_{2}^{2-}$ & 10.5 & - & $\begin{array}{l}\text { Buffle, Chalmers, Masson, } \\
\text { Midgley (1988) }\end{array}$ \\
\hline $\mathrm{Pb}^{2+}+\mathrm{SO}_{4}^{2-} \rightleftharpoons \mathrm{PbSO}_{4}$ & 2.75 & - & Smith and Martell (1976) \\
\hline
\end{tabular}




\begin{tabular}{|l|c|c|l|}
\hline Equilibrium & $\log \boldsymbol{K}^{\boldsymbol{\theta}}$ & $\boldsymbol{\Delta} \mathbf{H}^{\boldsymbol{\theta}}\left(\mathbf{k J} \mathbf{~ m o l}^{-1}\right)$ & Reference \\
\hline $\mathrm{Pb}^{2+}+\mathrm{Cl}^{-} \rightleftharpoons \mathrm{PbCl}^{+}$ & 1.59 & 18.4 & Smith and Martell (1976) \\
\hline $\mathrm{Pb}^{2+}+2 \mathrm{Cl}^{-} \rightleftharpoons \mathrm{PbCl}_{2}$ & 1.8 & - & Smith and Martell (1976) \\
\hline
\end{tabular}


Table S5. Constants for metal binding to fulvic acid in WHAM/Model VI. All from Tipping (1998) except where noted.

\begin{tabular}{|l|c|l|}
\hline Metal & $\log \boldsymbol{K}_{\mathbf{M A}}$ & $\boldsymbol{\Delta} \boldsymbol{L K}_{\mathbf{2}}$ \\
\hline $\mathrm{Mg}$ & 1.1 & 0.12 \\
\hline $\mathrm{Al}$ & 2.5 & 0.46 \\
\hline $\mathrm{Ca}$ & 1.3 & 0 \\
\hline FeIII $^{\mathrm{a}}$ & 2.6 & 2.20 \\
\hline $\mathrm{Cu}$ & 2.1 & 2.34 \\
\hline $\mathrm{Zn}$ & 1.6 & 1.28 \\
\hline $\mathrm{Cd}$ & 1.6 & 1.48 \\
\hline $\mathrm{Pb}$ & 2.2 & 0.93 \\
\hline
\end{tabular}

${ }^{a} \log K_{\text {MA }}$ from Tipping, Rey-Castro, Bryan, Hamilton-Taylor, 2002. 
Table S6. Kinetic constants for metal transfers among the labile, weakly aged and strongly aged pools.

\begin{tabular}{|l|c|c|c|c|c|}
\hline Metal & $\log \boldsymbol{k}_{\mathbf{f}, \mathbf{a}}$ & $\log \boldsymbol{k}_{\mathbf{b}, \mathbf{a}}$ & $\log \boldsymbol{k}_{\mathbf{f}, \mathbf{m}}$ & $\log \boldsymbol{k}_{\mathbf{b}, \mathbf{m}}$ & Reference \\
\hline $\mathbf{C u}$ & $-2.5+10^{-3.3} e^{\mathrm{pH}_{\mathrm{pw}}}$ & $-2.1+10^{-3.5} e^{\mathrm{pH}_{\mathrm{pw}}}$ & -5 & $-6.25^{\mathrm{a}}$ & $\mathrm{b}$ \\
\hline $\mathbf{Z n}$ & $-4.2+0.26 \mathrm{pH}_{\mathrm{pw}}$ & -3.2 & -5 & $-5.90^{\mathrm{a}}$ & $\mathrm{b}$ \\
\hline $\mathbf{C d}$ & $-2.9+0.18 \mathrm{pH}_{\mathrm{pw}}$ & -1.6 & -5 & $-5.34^{\mathrm{a}}$ & $\mathrm{b}$ \\
\hline $\mathbf{P b}$ & $-6.3+0.51 \mathrm{pH}_{\mathrm{pw}}$ & -2.6 & -5 & $-5.46^{\mathrm{a}}$ & this study \\
\hline
\end{tabular}

${ }^{a}$ Computed by calibration to observed total metal concentrations (see section IDMM initialisation)

${ }^{\mathrm{b}} \mathrm{Xu}$, Lofts and $\mathrm{Lu}$ (2016) 
Table S7. Parameters for critical limit functions.

\begin{tabular}{|l|c|c|c|}
\hline & $f$ & $g$ & $y$ \\
\hline $\mathrm{Cu}$ & 0.04 & -0.68 & 0.35 \\
\hline $\mathrm{Zn}$ & 0.36 & -1.09 & -2.12 \\
\hline $\mathrm{Cd}$ & 0.39 & -1.00 & -2.78 \\
\hline $\mathrm{Pb}$ & 0.05 & -0.66 & 1.03 \\
\hline
\end{tabular}


Table S8: Estimated TEs concentration in the crops of the 8-year rotational period of the ZOFE experiment.

\begin{tabular}{|c|c|c|c|c|c|c|}
\hline Metals & $\begin{array}{c}\text { Wheat } \\
{\left[\mathbf{m g ~ k g}^{-1}\right]}\end{array}$ & $\begin{array}{c}\text { Maize } \\
{\left[\mathbf{m g ~ k g}^{-1}\right]}\end{array}$ & $\begin{array}{c}\text { Barley } \\
{\left[\mathbf{m g ~ k g}^{-1}\right]}\end{array}$ & $\begin{array}{c}\text { Potato } \\
{\left[\mathbf{m g ~ k g}^{-1}\right]}\end{array}$ & $\begin{array}{c}\text { Sugar Beet } \\
{\left[\mathbf{m g ~ k g}^{-1}\right]}\end{array}$ & $\begin{array}{c}\text { Grass } \\
{\left[\mathbf{m g ~ k g}^{-1}\right]}\end{array}$ \\
\hline $\mathbf{Z n}$ & 27 & 26 & 27 & 46 & 23 & 40 \\
\hline $\mathbf{C u}$ & 5 & 3 & 5 & 4 & 10 & 9 \\
\hline $\mathbf{P b}$ & 0.035 & 0.035 & 0.035 & 0.030 & 0.052 & 0.046 \\
\hline $\mathbf{C d}$ & 0.097 & 0.097 & 0.097 & 0.059 & 0.059 & 0.100 \\
\hline
\end{tabular}




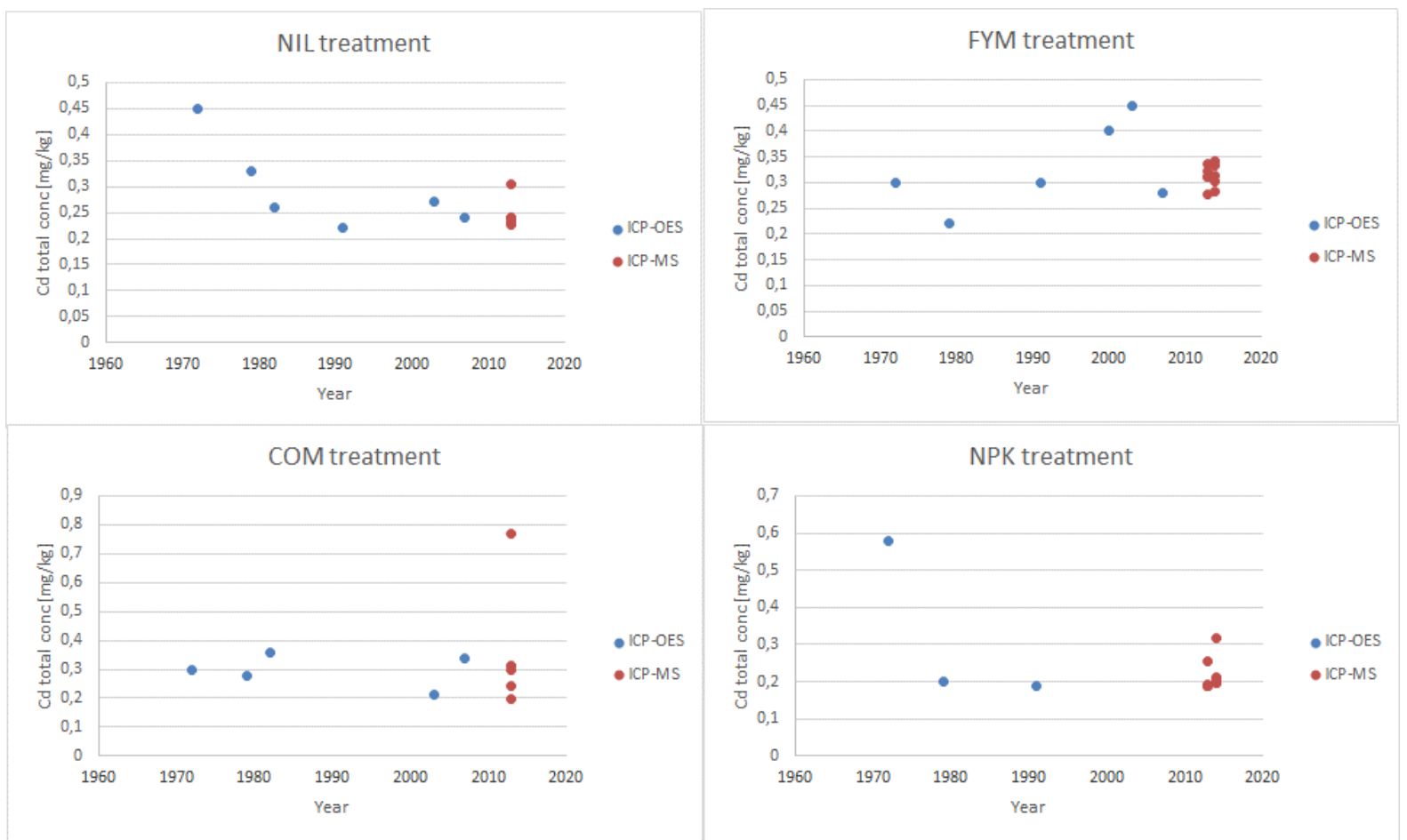

Figure S1: Comparison of Cd total concentrations measured respectively with ICP-OES in the laboratory of Dipartimento di Scienze e Tecnologie Agrarie, University of Florence, and ICPMS in the laboratory of the Institute of Terrestrial Ecosystems, ETH. 

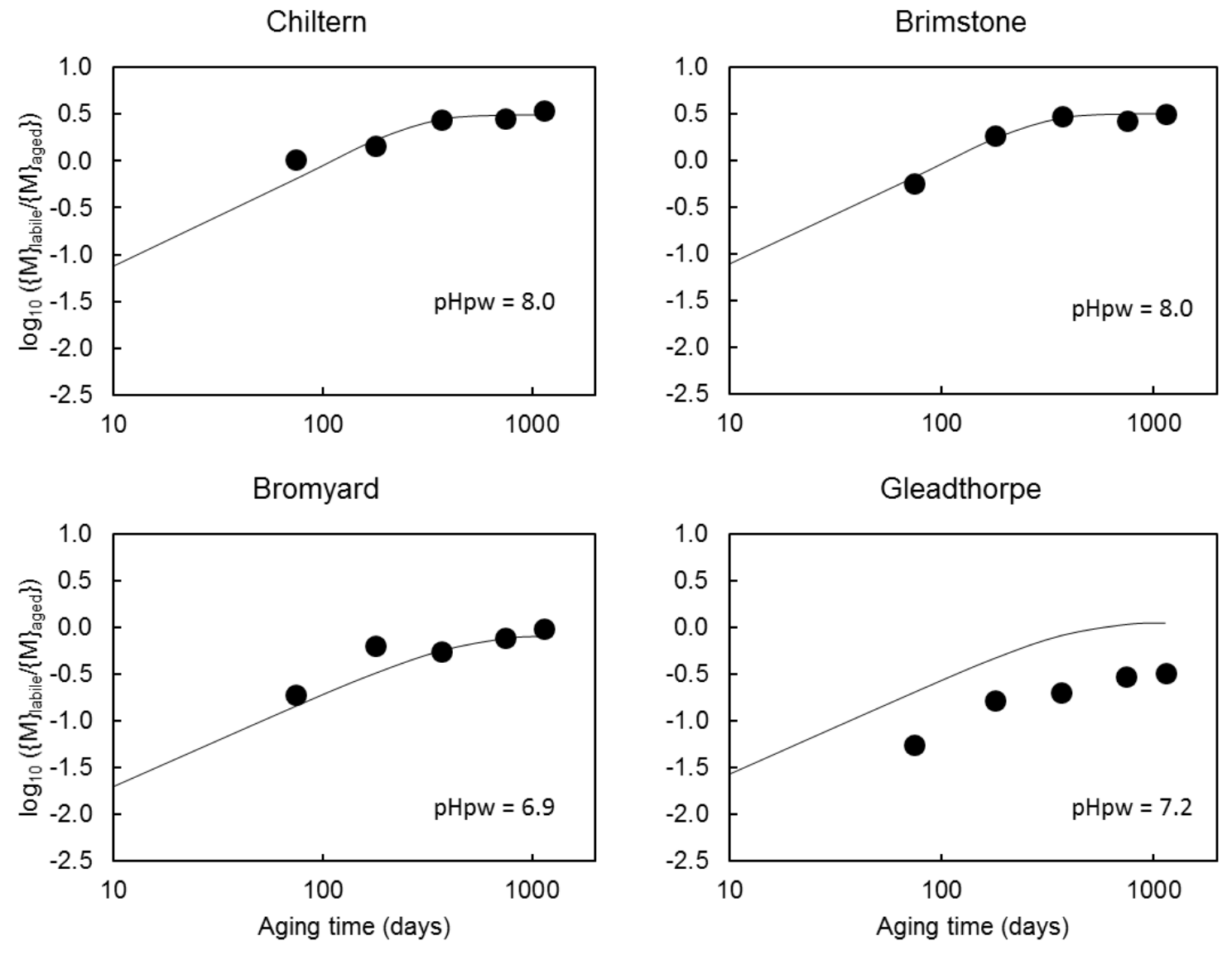

Figure S2. Aging of lead spikes in four UK soils. Lines are the result of model fitting to the expressions and parameters in Table S6. 


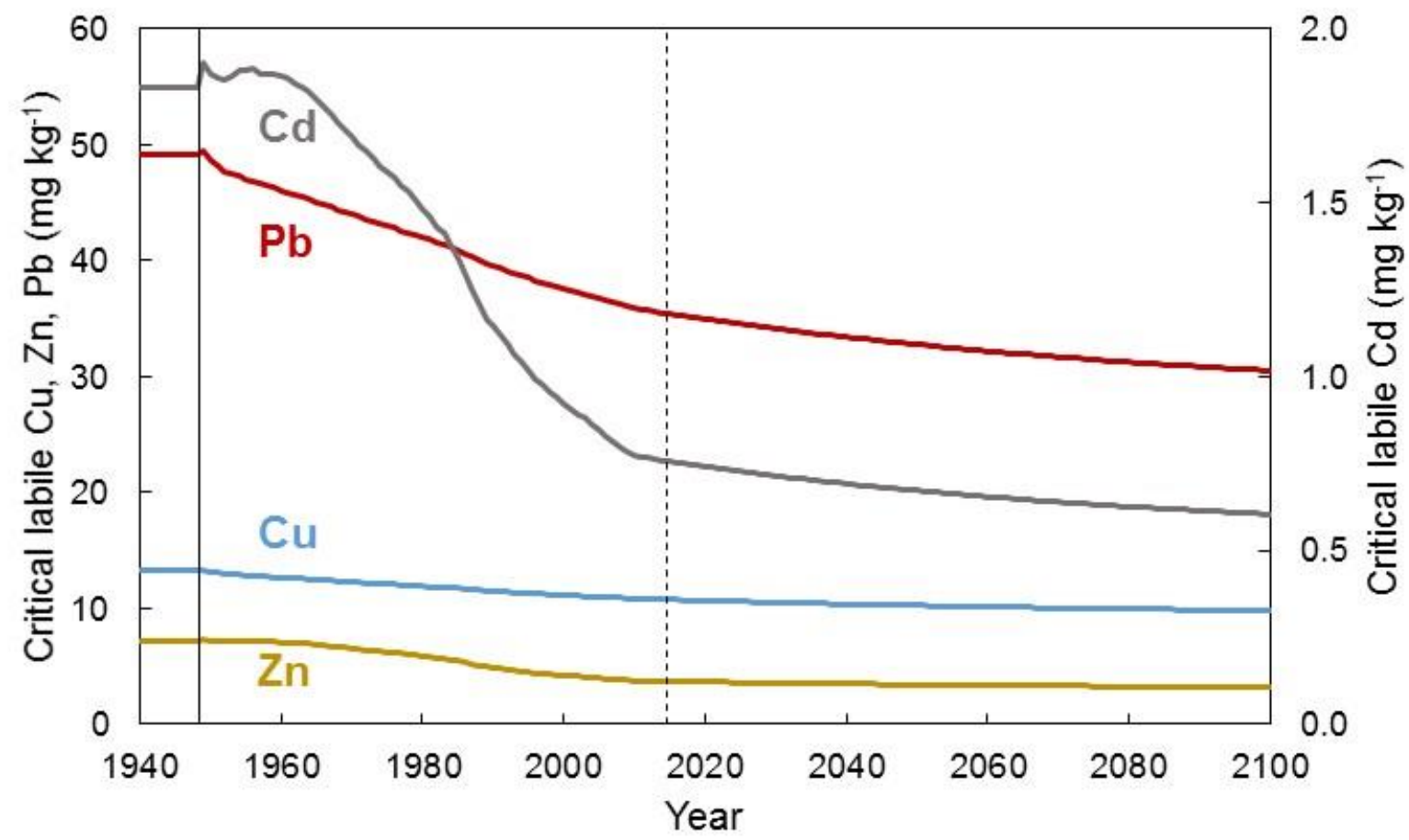

Figure S3. Example temporal trends in critical limit concentrations: limits in the SS plot soil from 1940 to 2100. The vertical solid represents the start of the ZOFE experiment. The dashed solid line represents the start of future projection. 


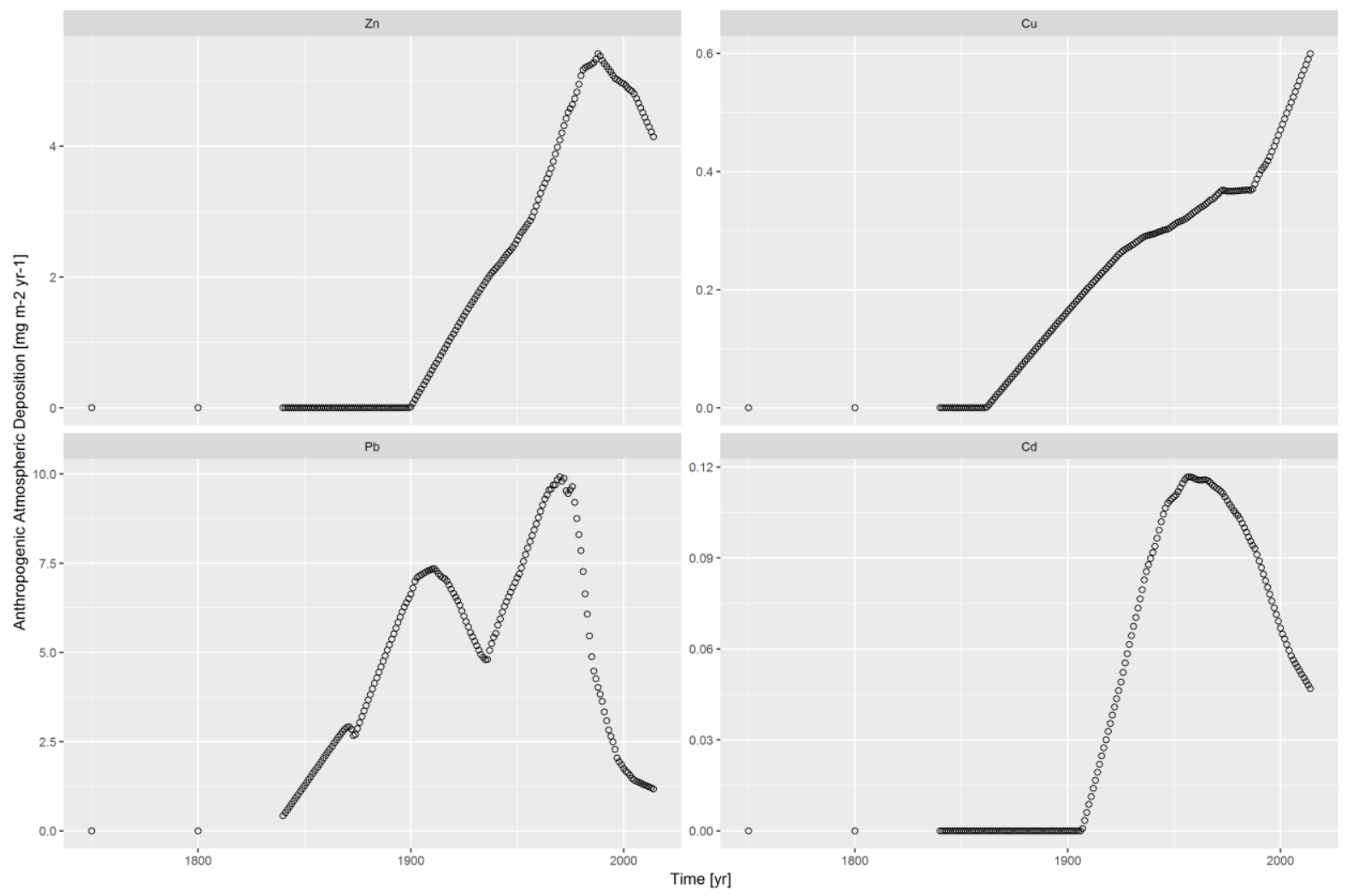

Figure S4: Estimated input fluxes of $\mathrm{Zn}, \mathrm{Cu}, \mathrm{Pb}, \mathrm{Cd}$ via anthropogenic atmospheric deposition. 

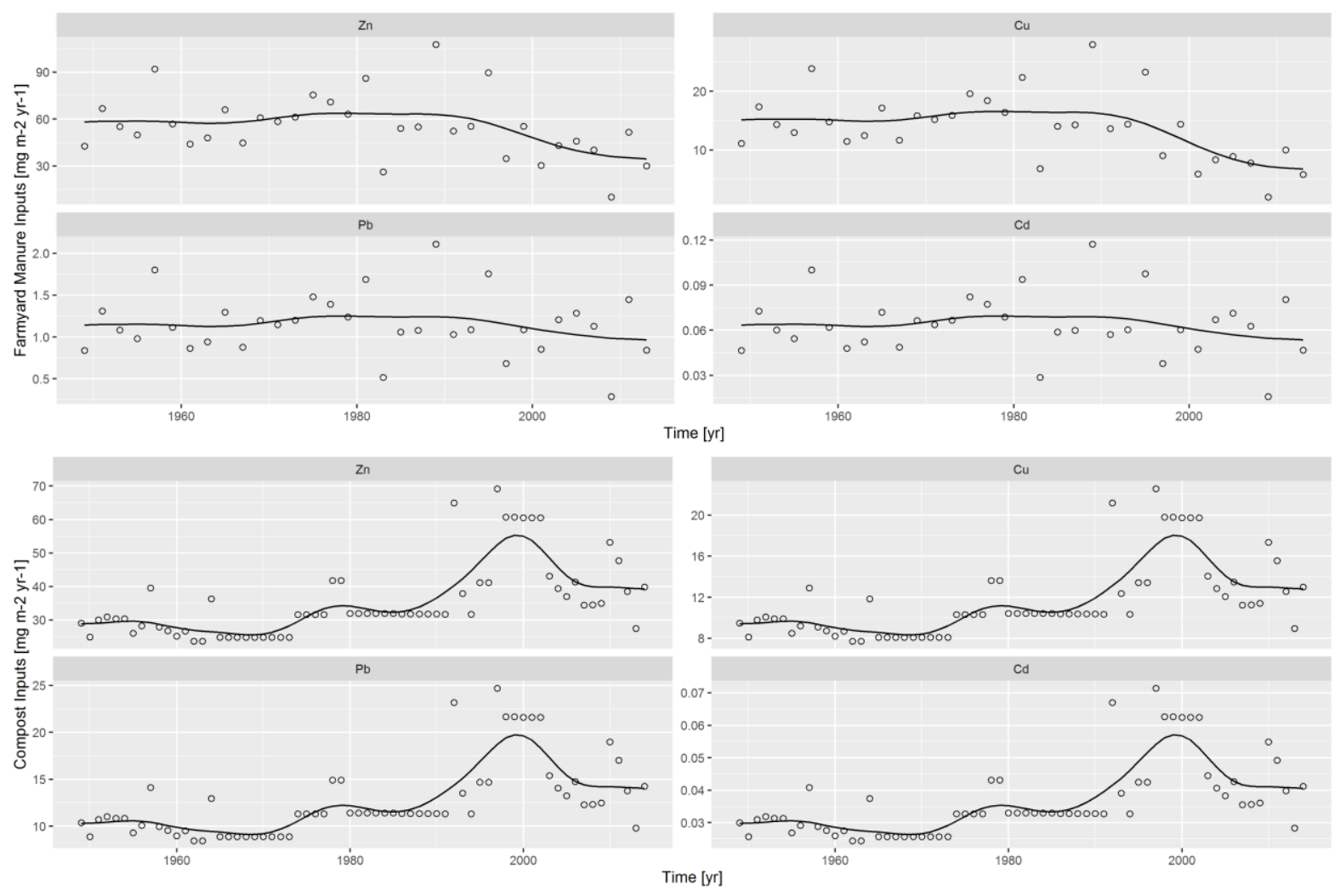

Figure S5: Estimated input fluxes of $\mathrm{Zn}, \mathrm{Cu}, \mathrm{Pb}, \mathrm{Cd}$ via application of farmyard manure and compost amendments. Smoothed trends used in the simulations are also reported. 

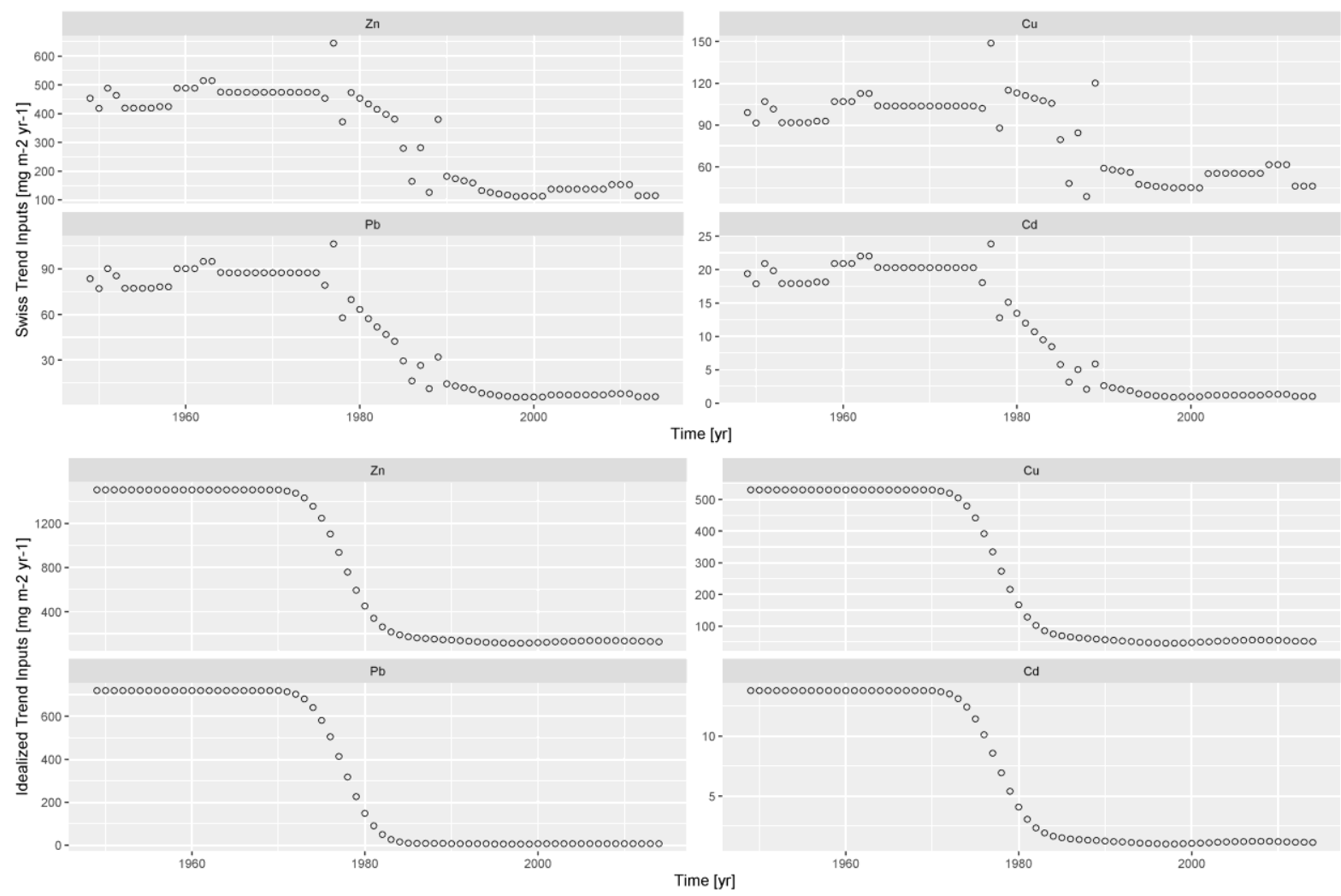

Figure S6: Estimated input fluxes of $\mathrm{Zn}, \mathrm{Cu}, \mathrm{Pb}, \mathrm{Cd}$ via application of the sewage sludge amendment according to the 'Swiss Trend' approach (top) and 'Idealised Trend' approach (bottom). 

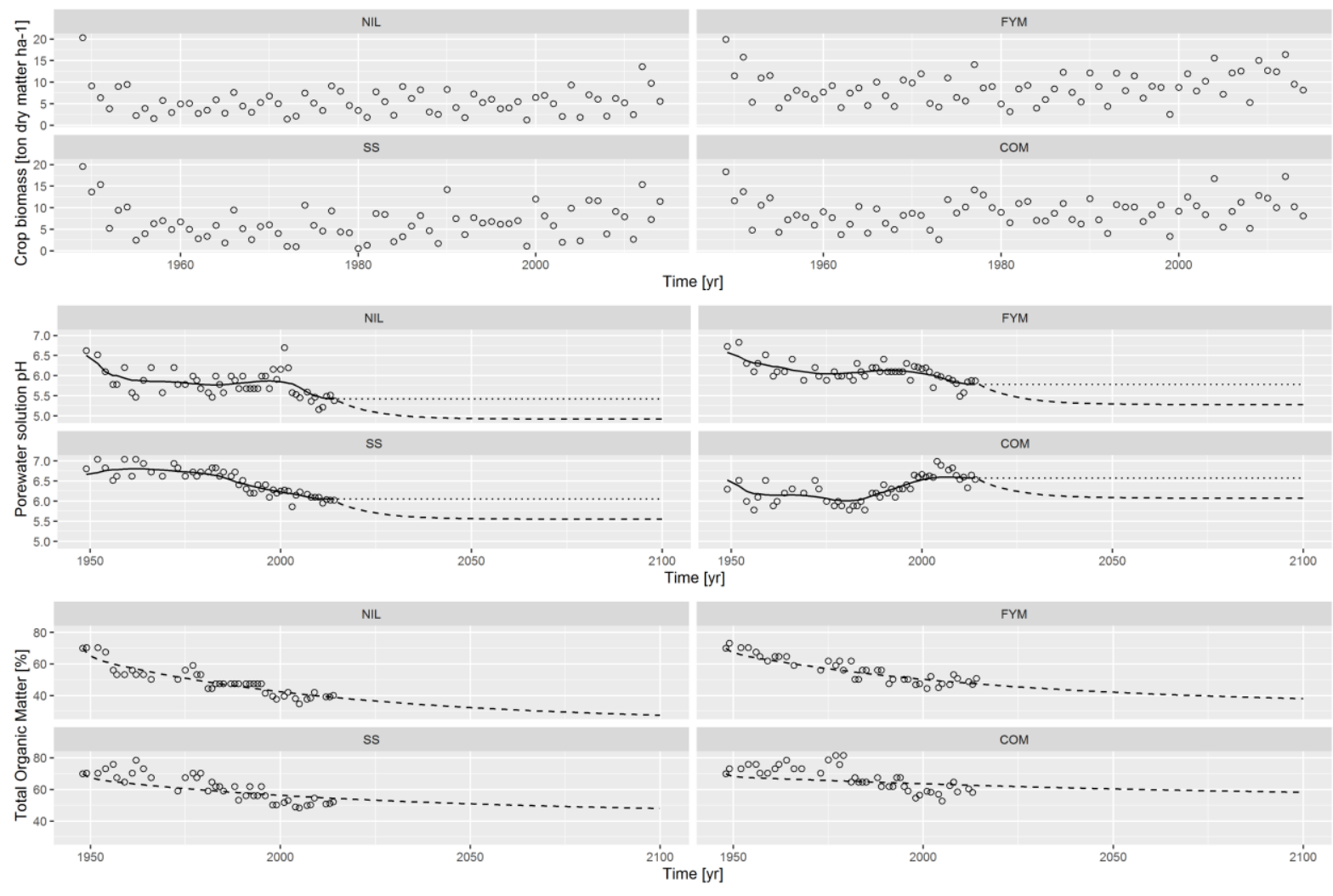

Figure S7: Estimated crop biomass, estimated soil solution pH (bullets) with smoothed curve (solid line) and two extrapolations, one constant (dotted line) and the other decreasing of 0.5 units (dashed line), measured (bullets) and simulated (line) SOM in the treatments NIL, FYM, SS, COM. 


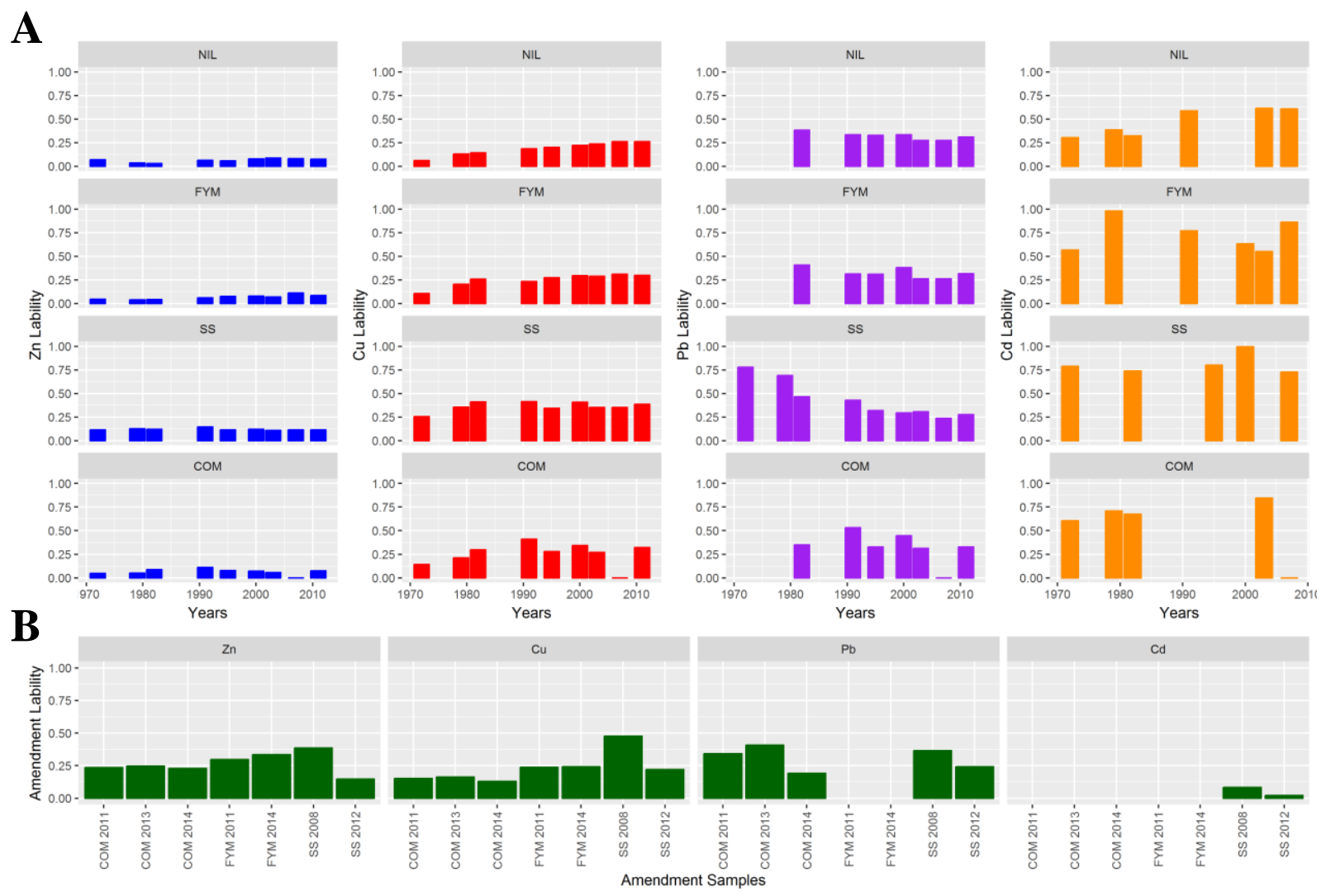

Figure S8: Lability time trends of $\mathrm{Zn}, \mathrm{Cu}, \mathrm{Pb}$ and $\mathrm{Cd}$, (A) in ZOFE topsoil $(0-20 \mathrm{~cm})$ for the treatments NIL, FYM, SS and COM; (B) in the organic amendment samples available. 

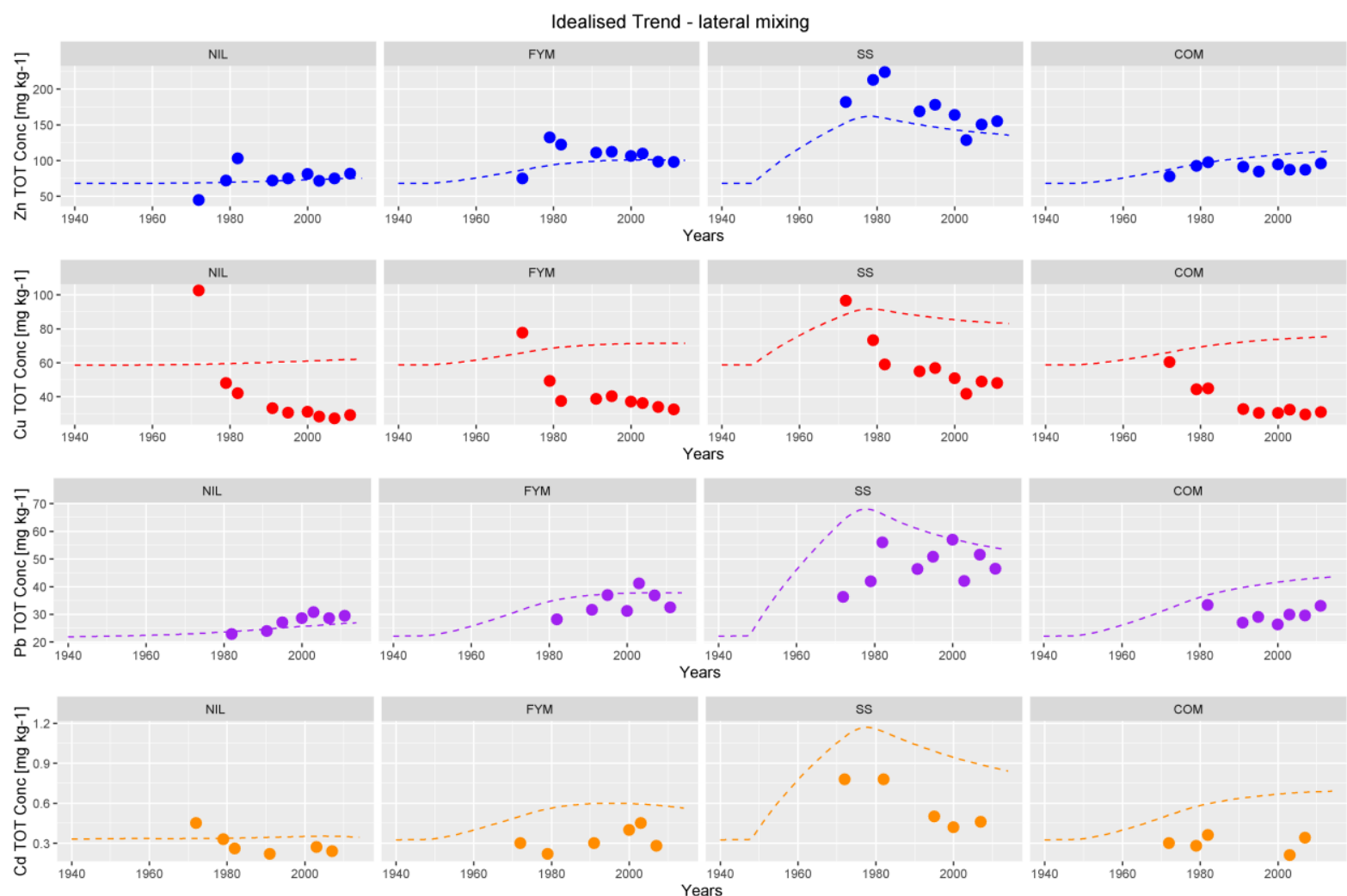

Figure S9: Observed total concentrations (bullets) and simulated total concentrations (solid lines) for $\mathrm{Zn}, \mathrm{Cu}, \mathrm{Pb}, \mathrm{Cd}$ in ZOFE topsoil $(0-20 \mathrm{~cm})$ for the treatments NIL, FYM, SS and COM. All the simulations are carried out with lateral mixing effect and the 'Idealised trend' approach. 


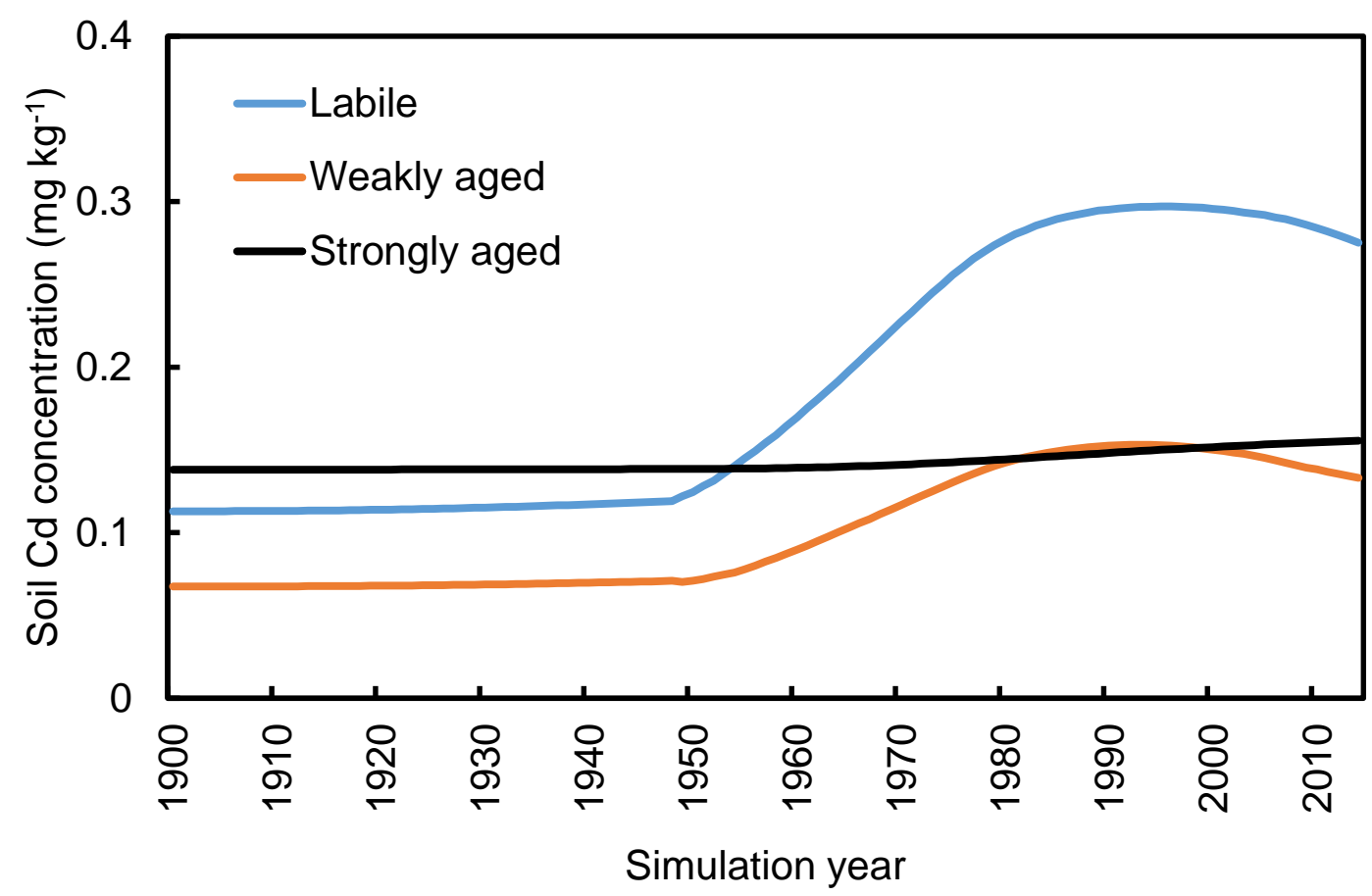

Figure S10. Example of predicted trends in labile, weakly aged and strongly aged metal concentrations, for Cd in the FYM plot. 


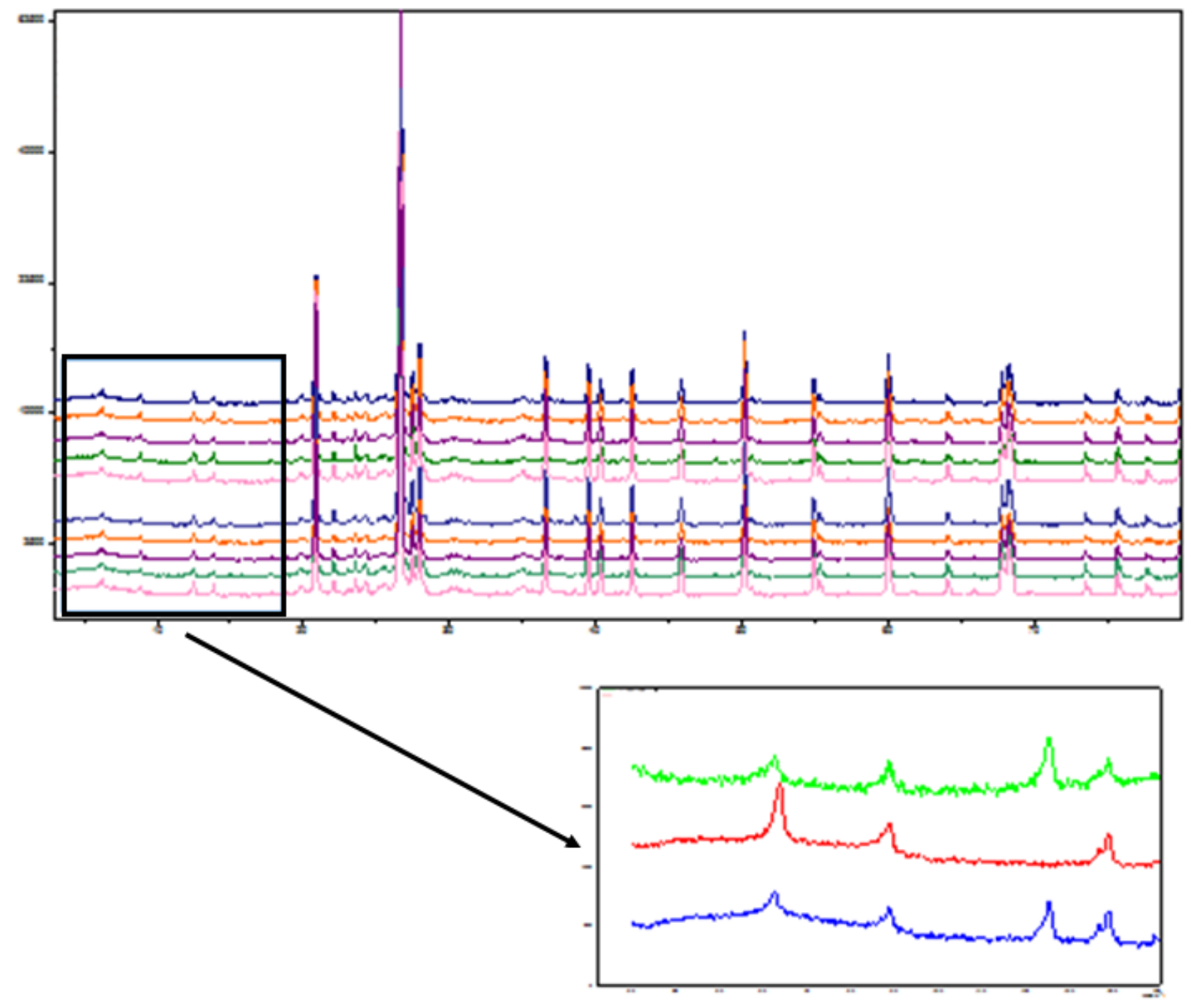

Figure S11: XRD diffractograms of NIL, FYM and COM soil samples from 1972 and 2011 and 2013. 


\section{Addendum to 2.6 Analysis of the soil and organic amendment FTIR and XRD}

The most noticeable peaks in the FTIR spectra were attributed as follows: $3624 \mathrm{~cm}^{-1}$ (Al-OH) vibrations, probably caused by fine material like clay $(\mathrm{Cl}) ; 2920 \mathrm{~cm}^{-1}$ and $2850 \mathrm{~cm}^{-1}$ (aliphatic groups asymmetric and symmetric $-\mathrm{CH}$ stretching, respectively), $\left(\mathrm{OM}_{1}\right) ; 1850 \mathrm{~cm}^{-1}, 810 \mathrm{~cm}^{-1}$ $696 \mathrm{~cm}^{-1}$ quartz $\left(\mathrm{Q}_{1}, \mathrm{Q}_{2}, \mathrm{Q}_{3},\right) ; 1630 \mathrm{~cm}^{-1}$ (aromatic $-\mathrm{C}=\mathrm{O}$ stretch and/or asymmetric of $\mathrm{COOH}) ; 1650 \mathrm{~cm}^{-1}$ and $1550 \mathrm{~cm}^{-1}$ [amide I $(-\mathrm{C}=\mathrm{O}$ of amide group) and amide II $(\mathrm{N}-\mathrm{H}$ bending), respectively], $\left(\mathrm{OM}_{2}\right) ; 1460 \mathrm{~cm}^{-1}\left(-\mathrm{CH}\right.$ deformation of $\left.\mathrm{CH}_{3}\right),\left(\mathrm{OM}_{3}\right)$; and $1040 \mathrm{~cm}^{-1}$ (-C-O stretching of polysaccharide or polysaccharide-like) $\left(\mathrm{OM}_{4}\right)$.

NIL, FYM, SS and COM amended soil samples from 1972 and 2011 and SS sample from 2013 were analysed by X-ray diffractometry (XRD). The investigation was conducted on randomlyoriented powders of bulk soil by a Philips PW3830 X-ray diffractometer with CoK $\alpha$ radiation, $0.02^{\circ}$ step size, and $1 \mathrm{~s}$ step time each point over a $2 \theta$ range of $5-75^{\circ}$. 